\title{
New Single Rod Implant Innovation in Indonesia
}

\author{
Eka Rusdianto Gunardi* and Denny Khusen \\ Department of Obstetrics and Gynecology, Universitas Indonesia/Dr Cipto Mangunkusumo Hospital, Indonesia
}

*Corresponding author: Eka Rusdianto Gunardi, Department of Obstetrics and Gynecology, Faculty of Medicine Universitas Indonesia/Dr Cipto Mangunkusumo Hospital, Jakarta, Indonesia.

To Cite This Article: Eka Rusdianto Gunardi. New Single Rod Implant Innovation in Indonesia. Am J Biomed Sci \& Res. 2019 - 3(4). AJBSR. MS.ID.000691. DOI: 10.34297/AJBSR.2019.03.000691

Received: June 18, 2019 | Published: June 24, 2019

\begin{abstract}
The term implant is familiar in Indonesia because it is cultural and mystical, such as the beauty implant, black magic implant, and also popular for contraception. A contraceptive implant is an implantable medical device used for the purpose of birth control. The implant may depend on the timed release of hormones to hinder ovulation or sperm development, the ability of copper to act as a natural spermicide within the uterus, or it may work using a non-hormonal, physical blocking mechanism. As a country with the largest implant acceptors in the world, Indonesia has developed implant that consists of single rod called Monoplant $₫$. Monoplant $®$ is expected to be the best option because it only consists of a single rod implant that is easy to insertion and remove, effective and safe for at least three years [1,2].
\end{abstract}

\section{Opinion}

Implant is a contraceptive device that is placed under the skin, containing steroid hormones and are used for a long time; one of them is the levonorgestrel implants. Indonesia has developed its own implants, monoplant ${ }^{\circledR}$ which is contains one LNG rods. Levonorgestrel-releasing implant is $99 \%$ - 99.95\% effective at preventing pregnancy, and is one of the most reliable, though not the most available, forms of birth control. Levonorgestrelreleasing implant prevents pregnancy through multiple methods: by preventing ovulation, which means that no eggs are released for fertilization; by thickening the mucus of the cervix, which prevents sperm from entering; and by thinning the lining of the uterus, which makes implantation of an embryo less likely $[3,4]$.

Monoplant ${ }^{\circledR}$ will only have single rod to insert in the upper arms causing the advantages of insertion and removal easily. This single rod implant is now undergoing for research in the third stage of clinical trial. Monoplant $\AA^{\circ}$ as new breakthrough for long-term contraceptive method in Indonesia is expected to be effective and efficient contraception in Indonesia. This implant is being promoted in Indonesia so that it can be used in various health facilities and can be one of the country's programs to be free in the community [5-7].

We had already performed research about the efficacy of Monoplant $\AA$ and Indoplant $\AA$ as contraceptive methods: a comparative study. Researchers want to determine the effectiveness, safety, and time of insertion between Monoplant ${ }^{\circledR}$ with Indoplant ${ }^{\circledR}$ to prevent pregnnancy. The data obtained showed no significant difference in the effectiveness of both contraceptive methods. In addition, side effects such as menstrual disorders and weight gain did not differ significantly in those study groups. From that research, both implants have the same effectiveness, safety, no differences in weight gain and menstrual disorders during 1, 3, and 6 months follow-up. However, the insertion of Monoplant $\AA$ are faster than Indoplant $\AA^{\circledR}$. Monoplant $\AA$ can be used as a contraceptive method with the same effectiveness and safety as Indoplant $\AA^{\circledR}$, yet with shorter insertion time [5]

We believe that this advancement will bring a new hope to increase the efficacy of national contraception program.

\section{Conflict of interest}

There is no conflict of interest declared and this manuscript has not been published or under consideration for publication elsewhere.

\section{References}

1. McDonald Mosley R, Burke AE (2010) Contraceptive implants. Semin Reprod Med 28(2): 110-117.

2. Steiner MJ, Lopez LM, Grimes DA, Cheng L, Shelton J, et al. (2010) Sinoimplant (II)- a levonorgestrel-releasing two-rod implant: systematic review of the randomized controlled trials. Contraception 81(3): 197201.

3. Gunandi E, Affandi B, Muchtar A (2011) Monoplant® the Indonesian Implant: The Overview of Implant and Its Development, Indonesian.

4. Gunardi ER (2011) Levonorgestrel concentration in a single rod implant user for six months. Indones J Obstet Gynecol 35(3): 122-127. 
5. Gunardi E, Ballo F (2017) The Efficacy of Monoplant $\AA$ and Indoplant ( as Contraceptive Methods: A Comparative Study. Indonesian Journal of Obstetrics and Gynecology 5(2): 94-98.

6. Gunardi E, Affandi B (2014) Serum levonorgestrel concentration and cervical mucus viscosity after six months of monoplant ${ }^{\circledR}$ implantation. Med J Indones 23(1): 25-29.
7. Gunardi E (2019) Indonesian Single Rod Implant: A New Breakthrough. American Journal of Biomed Science \& Research 1(6): 252-253. 